\title{
INFLUENGE OF FENCING TRAINING (TECHNICAL AND TACTICAL) ON SELECTED FEATURES OF SHAPE OF THE SPINE AND PELVIS UNDER LOAD
}

\author{
Alicja Kaiser, ${ }^{1, A, B, C, D, ~ E}$ Marek Sokołowski, , , A, B, C, D Mirosław Mrozkowiak 3 , A, B, C, D \\ ${ }^{1}$ WSB University in Poznań, Department of Didactics of Tourism and Recreation, Poland \\ ${ }^{2}$ University School of Physical Education in Poznań, Department of Sports and Defence Education, Poland \\ ${ }^{3}$ Kazimierz Wielki University in Bydgoszcz, Department of Physiotherapy, Poland \\ A Study Design; ${ }^{B}$ Data Collection; ${ }^{C}$ Statistical Analysis; ${ }^{D}$ Manuscript Preparation; E Funds Collection

\section{Address for corpespondence:} \\ Alicja Kaiser \\ WSB University in Poznań, Department of Didactics of Tourism and Recreation \\ Powstańców Wielkopolskich 5, 61-895 Poznań, Poland \\ E-mail: alicja_kaiser@poczta.fm
}

\begin{abstract}
Ahstract The aim of the research was to assess influence of a 90-minute specialist fencing training on selected features of the spine and pelvis under a vertical load in a group of young competitors.

The research was carried out in 2015 among 23 fencers (mean \pm SD, age: $16 \pm 1.20$ years; body height: $168.4 \pm 4.68 \mathrm{~cm}$; body weight: $54.7 \pm 8.26 \mathrm{~kg}$ ). The method involved measurement of thirty features, describing spatially pelvis and physiological spinal curvature under a vertical load, constituting $1 / 3$ of the body weight before and after specialist training.

Statistically significant disturbances in vertically overstretched posture occurred after the training among examined boys within the following features: increase in length of left side scoliosis, progression of lumbar lordosis and lumbosacral spine, increase of the trunk extension angle and shoulder asymmetry. Among examined girls statistically significant changes occurred only within pelvis area: increase of left pelvic tilt in the coronal plane, decrease of right pelvic tilt in the horizontal plane.

Adjustment in deficiencies within hip joints movement, increase pelvis and lower limbs muscle strength in girls' training is necessary. What is recommended for all competitors is prophylaxis of the spinal pain syndrome and expanding endurance shaping exercises during a training unit.
\end{abstract}

Key Worlds posture, spine, pelvis, kyphosis, fencing

\section{Introduction}

Asymmetry of human body is a physiological phenomenon, the trouble - however - is to establish acceptable range of this asymmetry. Research by Kingma et al. (1998) and by Young, Andrew, Cummings (2000) show that every asymmetry, static or dynamic, is a basis for overload disturbances.

The ability to transfer vertical load is conditioned, among others, by the symmetry of the spine in the coronal plane and by the optimal values of angles of physiological curvatures in the median plane. The disturbed function of the pelvis in the median plane might lead to changes in angular values of physiological curvatures, whereas 
disturbances in a coronal or horizontal plane result in an asymmetrical profile of the line of spinous processes. A proper muscle tone is essential for a correct body posture and motor activity. It should be sufficient to prevent the effect of gravitational forces and low enough to allow for smooth selective movements or isolated activity (Shumway-Cook, Woollacott, 2000). The efficiency of the system of body posture control depends on the internal and external determinants, such as fatigue, emotional states, body temperature, atmospheric pressure and other factors (Perrot, Mur, Maynard, Barrault, Perrin, 2000).

Modern training regimes in professional sports involve doing repeated strenuous exercises that require enormous endurance of the skeletal system, especially the spine. The majority of sports disciplines affect human vertebral column (Mroczkowski, Jaskólski, 2007; López-Miñarro, Muyor, Alacid, 2010; Mrozkowiak, Sokołowski, Kaiser, 2012; Rajabi, Mobarakabadi, Alizadhen, Hendrick, 2012; Flis-Masłowska, Trzaska, Wiernicka, Lewandowski, 2014). For example, tennis is a frequent cause of abnormalities in the lower lumbar spine at $L 4 / 5$ and $L 5 / S 1$ levels; lumbar pars injuries and facet joint arthroses are relatively common diseases among tennis players (Alyas, Turner, Connell, 2007). The examination of young sumo wrestlers showed a significant correlation between spondylolysis and lumbar symptoms which indicates that young sumo wrestlers give up to continue this sport because of symptomatic spondylolysis (Nakagawa, Mukai, Hattori, Nakamura, 2011).

Cervical spine abnormalities consisting of degenerative discopathy are observed in professional male rugby players aged $>21$ years, as shown in the study carried out among French rugby union clubs between 2002 and 2006 (Castinel, Adam, Milburn, 2010). The spine is even more exposed to injury in sports involving additional load, e.g. an opponent or partner (wrestling, judo, figure skating) or several partners (human pyramids in acrobatic gymnastics), or in disciplines which require sports equipment (weightlifting or hammer throw) (Starosta, 1993). High control of body posture is crucial in acrobatics, air racing, track and field or combat sports. The results of the studies examining effects of disturbances on the performance of the system of body posture control are useful when working with athletes and caring for their health.

The aim of research is to assess the influence of a 90-minute specialist fencing training (technical and tactical exercises) on selected features of the spine and pelvis under vertical load in a group of young competitors.

\section{Material and methods}

The research was carried out in October 2015 at the Sports and Recreation Centre in Drzonków during a sports grouping in a competition season. It is a part of longitudinal research that has been carried out since 2013 (Mrozkowiak, Kaiser, Sokołowski, 2015). It involved 23 fencers, aged 15-18 years (11 boys and 12 girls). The average body weight was $54.7 \mathrm{~kg}$, height $168.4 \mathrm{~cm}$, and training duration 5.5 years (Table 1).

An attempt to reach the scientific aim was resulting from the need of gaining a comprehensive outlook on vertically loaded habitual posture of competitors. Essential in this method is simultaneousness in measuring all values of spatial parameters of particular body parts. The examination was carried out before and after a training (90 minutes) with axial load of the spine adjusted individually for each competitor. It was assumed that the load of a third of a competitor's body weight, placed symmetrically on the pectoral girdle will significantly change analysed postural features. This assumption took into consideration changes in skeleton and musculature occurring in the developmental age, as well as sports profile during the start period of a training cycle. 
Tahle 1. Sample group N = 23 (boys $=11$, girls $=12$ )

\begin{tabular}{cccccc}
\hline Number & Initials & Birth & $\begin{array}{c}\text { Weight } \\
(\mathrm{kg})\end{array}$ & $\begin{array}{c}\text { Height } \\
(\mathrm{cm})\end{array}$ & $\begin{array}{c}\text { Training } \\
\text { duration } \\
(\text { years })\end{array}$ \\
\hline 1. & M.J. & 1998 & 39 & 159 & 4 \\
2. & K.D. & 1996 & 67 & 186 & 7 \\
3. & R.R. & 1997 & 64 & 178 & 5 \\
4. & G.M. & 1996 & 56 & 170 & 8 \\
5. & G.A. & 1996 & 59 & 170 & 6 \\
6. & K.K. & 1996 & 74 & 176 & 7 \\
7. & O.O. & 1997 & 60 & 179 & 4 \\
8. & M.A. & 1996 & 51 & 156 & 6 \\
9. & V.M. & 1996 & 53 & 166 & 7 \\
10. & M.K. & 1998 & 48 & 163 & 4 \\
11. & P.D. & 1998 & 49 & 163 & 5 \\
12. & W.W. & 1999 & 55 & 159 & 3 \\
13. & B.Z. & 1998 & 49 & 158 & 5 \\
14. & G.W. & 1998 & 43 & 158 & 6 \\
15. & W.Z. & 1996 & 57 & 169 & 6 \\
16. & M.Z. & 1996 & 54 & 167 & 10 \\
17. & P.R. & 1996 & 61 & 176 & 8 \\
18. & S.A. & 1996 & 54 & 164 & 6 \\
19. & L.K. & 1996 & 66 & 184 & 5 \\
20. & P.M. & 1999 & 53 & 167 & 4 \\
21. & K.F. & 1998 & 53 & 167 & 5 \\
22. & S.J. & 1998 & 40 & 159 & 5 \\
23. & K.A. & 1999 & 54 & 180 & 4 \\
\hline Mean values \pm SD. & $16 \pm 1.20$ & $54.7 \pm 8.26$ & $168.4 \pm 4.68$ & $5.5 \pm 1.41$ \\
\hline & & & & & \\
\hline & & & & & \\
\hline
\end{tabular}

In the evaluation a computer-based postural analysis device was used. It consists of a computer with specialist software and a camera to measure selected parameters of pelvis-spine system. Thanks to projecting lines on a patient's back, spatial visualisation is presented. Those lines, while projected on the patient's back, deform depending on the surface. The picture is then sent to the computer. Deformities of lines recorded by the computer are transformed by a numerical algorithm (Mrozkowiak, 2011). The results, in form of a spatial graphic picture, enable to describe analysed features numerically. The line values reflect the distance of selected anthropometric points on the patient's back, while the angle values describe the deviation in setting in relation to the horizontal or distance from the camera. Received picture allows for a multi-faceted interpretation of body posture. Apart from assessment of trunk asymmetry in the plane coronal, there is a possibility of determining spatial values of angle and line parameters describing pelvis, physiological curvatures and coronal asymmetry of spinous processes, i.e. the deviation of the topmost spinous process from C7-S1 line. A short time of recording helps to avoid fatigue of postural muscles, which is often while examinations performed with use of somatoscopy. The most important in this method was that all measurements of spatial parameters were carried out simultaneously (Table 2). 
Table 2. Recorded parameters of the pelvis-spine system

\begin{tabular}{|c|c|c|c|c|}
\hline \multirow{2}{*}{ No. } & \multirow{2}{*}{ Symbol } & \multicolumn{3}{|c|}{ Parameters } \\
\hline & & unit & name & description \\
\hline \multicolumn{5}{|c|}{ Plane median } \\
\hline 1. & Alpha & degrees & Lumbar-sacral curvature & \\
\hline 2. & Beta & degrees & Thoracic-lumbar curvature & \\
\hline 3. & Gamma & degrees & Upper thoracic curvature & \\
\hline 4. & Delta & degrees & Total value of angles & Delta $=$ Alpha + Beta + Gamma \\
\hline 5. & DCK & $\mathrm{mm}$ & Total length of spine & Distance between $\mathrm{C} 7$ and $\mathrm{S} 1$ measured vertically \\
\hline 6. & KPT & degrees & Angle of trunk extension & Described in deviation of C7-S1 line from the vertical (backwards) \\
\hline 7. & KPT- & degrees & Angle of trunk lean & Described in deviation C7-S1 line from the vertical (forward) \\
\hline 8. & DKP & $\mathrm{mm}$ & Length of thoracic kyphosis & Distance between $\mathrm{LL}$ and $\mathrm{C7}$ \\
\hline 9. & KKP & degrees & Angle of thoracic kyphosis & KKP $=180-($ Beta + Gamma $)$ \\
\hline 10. & RKP & $\mathrm{mm}$ & Height of thoracic kyphosis & Distance between $\mathrm{C} 7$ and PL \\
\hline 11. & GKP & $\mathrm{mm}$ & Depth of thoracic kyphosis & $\begin{array}{l}\text { Distance measured horizontally between vertical lines crossing } \\
\text { PL and KP }\end{array}$ \\
\hline 12. & DLL & $\mathrm{mm}$ & Length of lumbar lordosis & Distance between S1 and KP \\
\hline 13. & KLL & degrees & Angle of lumbar lordosis & $\mathrm{KLL}=180-($ Alpha + Beta $)$ \\
\hline 14. & RLL & $\mathrm{mm}$ & Height of lumbar lordosis & Distance between $\mathrm{S} 1$ and $\mathrm{PL}$ \\
\hline 15. & GLL- & $\mathrm{mm}$ & Depth of lumbar lordosis & $\begin{array}{l}\text { Distance measured horizontally between vertical lines crossing } \\
\text { PL and LL }\end{array}$ \\
\hline \multicolumn{5}{|c|}{ Plane coronal } \\
\hline 16. & KNT- & degrees & \multirow{2}{*}{ Angle of trunk tilt sideways } & Determined by deviation of C7-S1 line from the vertical to the left \\
\hline 17. & KNT & degrees & & Determined by deviation C7-S1 from the vertical to the right \\
\hline 18. & LBW- & $\mathrm{Mm}$ & Right shoulder higher & \multirow{2}{*}{$\begin{array}{l}\text { Distance measured vertically between horizontal lines crossing } \\
\text { B2 and B4 }\end{array}$} \\
\hline 19. & LBW & $\mathrm{Mm}$ & Left shoulder higher & \\
\hline 20. & LŁW & $\mathrm{Mm}$ & Left scapula higher & \multirow{2}{*}{$\begin{array}{l}\text { Distance measured vertically between horizontal lines crossing } \\
\lfloor 1 \text { and } Ł p\end{array}$} \\
\hline 21. & LŁW- & $\mathrm{Mm}$ & Right scapula higher & \\
\hline 22. & $\mathrm{OL}$ & $\mathrm{Mm}$ & Interior angle of the left scapula is further & \multirow{2}{*}{$\begin{array}{l}\text { Difference in distance of the interior angles of the scapulae from } \\
\text { the line of spinous processes, measured horizontally on lines } \\
\text { crossing } Ł \text { and } Ł p\end{array}$} \\
\hline 23. & OL- & $\mathrm{Mm}$ & Interior angle of the right scapula is further & \\
\hline 24. & KNM & degrees & Angle of pelvic tilt, the right ala higher & \multirow{2}{*}{ Angle between the horizontal line and a line crossing M1 and Mp } \\
\hline 25. & KNM- & degrees & Angle of pelvic tilt, the left ala higher & \\
\hline 26. & UK (dex) & $\mathrm{Mm}$ & Maximal deviation of a spinous process to the right & \multirow{2}{*}{$\begin{array}{l}\text { The highest deviation of a spinous process from the horizontal led } \\
\text { from S1. The distance measured along horizontal axis. }\end{array}$} \\
\hline 27. & UK- (sin) & $\mathrm{Mm}$ & Maximal deviation of a spinous process to the left. & \\
\hline \multicolumn{5}{|c|}{ Plane axial } \\
\hline 28. & KSM & degrees & Right pelvic tilt & $\begin{array}{l}\text { Angle between the line crossing Ml, perpendicular to camera axis } \\
\text { and the line crossing Ml and MP }\end{array}$ \\
\hline 29. & KSM- & degrees & Left pelvic tilt & $\begin{array}{l}\text { Angle between the line crossing Mp, perpendicular to camera axis } \\
\text { and the line crossing Ml and MP }\end{array}$ \\
\hline
\end{tabular}

In order to minimalize risk of error the following examination procedure was observed:

1. Marking antropometric points in habitual posture. Marking on the skin of examined person: the peak of spinous process in the last cervical vertebra (C7), spinous process marking the peak of thoracic kyphosis $(\mathrm{KP})$, spinous process marking the peak of lumbar lordosis (LL), space of transition between thoracic kyphosis into lumbar lordosis (PL), lower angles of scapulae ( $\measuredangle$ I and $Ł p)$, upper back iliac crest (Ml and $\mathrm{Mp})$, S1 vertebra. 
2. Maintaining habitual posture during examination and, in individual cases, even distribution of weight on lower limbs. It is particularly significant for people who have the tendency of habitual overburdening of one limb.

3. Calibration of reference point, levelling the diagnostic system. An error depends on carefulness and is difficult to assess. When the arrangement: camera - back surface is not observed. The light beam sent from the projecting and receiving device, as well as the long axis of the camera must be perpendicular to the line formed by big toes.

4. Positioning on the screen the characteristic points with use of cursor. It is important to define registered pictures carefully. Report is more accurate if the examined person stands against dimly lit background, and the picture is projected on a big screen. An error depends on technician's experience, screen resolution, blackout of the room.

5. Habitual posture of patient (casual, effortless, with feet slightly apart, knee and hip joints straight, arms along the trunk, eyes directed to the front) standing back to the camera in appropriate distance. The picture for analysis is recorded in the middle phase of free exhale.

6. After completing necessary data about patient (name and surname, date of birth, weight and height, information on: knees and heels, chest, injuries, surgeries, motor organs diseases, tread, etc) the computer saves digital picture of patient's back.

7. Compilation of pictures is carried out without patient's participation.

8. After saving mathematical characteristics of pictures, 30 parameters (Table 2) describing spatially the pelvis-spinal area are printed.

\section{Statistical analysis}

In order to describe the effect of vertical load on body posture, the results were analysed with use of statistical methods determining: minimal and maximal values, mean and median, standard deviation, coefficient of variation, skewness, kurtosis, and significance of differences in values of features before and after the training with vertical load.

\section{Results}

Significance of differences in body postures before and after training with vertical load is presented in Table 3 .

Among examined boys statistically significant changes in vertically loaded posture after training occurred within: increase in length of left side scoliosis, progression of lumbar lordosis and lumbosacral spine, increase of the torso inclination angle and shoulder asymmetry. At the same time, no disturbances were noted within thoracic kyphosis and lumbar lordosis (length, depth and angle), pelvis (pelvic tilt in the coronal plane and lateral in the horizontal plane). Among examined girls statistically significant changes occurred only within pelvis area: increase of left pelvic tilt in the coronal plane, decrease of right pelvic tilt in the horizontal plane. No statistically significant changes were observed in the plane median of the spine and the plane coronal of the trunk. 
Table 3. Significance of differences in selected features describing spatially body postures of fencers before (1) and after (2) training $N=23$ (boys $=11$, girls $=12$ )

\begin{tabular}{|c|c|c|c|c|c|c|c|}
\hline Symbol & M & SD & $\begin{array}{l}\text { Difference } \\
\text { in values before } \\
\text { and after training }\end{array}$ & $\begin{array}{l}\text { Standard } \\
\text { deviation }\end{array}$ & t & $d f$ & $\mathrm{P}$ \\
\hline \multicolumn{8}{|c|}{ Boys } \\
\hline DS 1 & 226.09 & 25.93 & & & & & \\
\hline DS 2 & 286.27 & 46.32 & -60.180 & 49.510 & -4.03 & 10 & 0.0023 \\
\hline KLL 1 & 163.27 & & & & & & \\
\hline KLL 2 & 160.72 & 3.79 & 2.450 & 3.610 & 2.33 & 10 & 0.0416 \\
\hline KPT 1 & 19.09 & & & & & & \\
\hline KPT 2 & 19.81 & 2.04 & -0.727 & 1.009 & -0.39 & 10 & 0.0130 \\
\hline KLB 1 & 2.09 & & & & & & \\
\hline KLB 2 & 7.63 & 9.36 & -5.540 & 7.630 & -2.40 & 10 & 0.0367 \\
\hline Alfa 1 & 5.90 & & & & & & \\
\hline Alfa 2 & 8.00 & 2.68 & -2.090 & 2.300 & -3.01 & 10 & 0.0130 \\
\hline \multicolumn{8}{|c|}{ Girls } \\
\hline KNM 1 & 4.08 & 4.87 & & & & & \\
\hline KNM 2 & 1.66 & 2.22 & 2.410 & 3.340 & 2.50 & 11 & 0.0292 \\
\hline KSM 1 & 1.75 & 2.05 & & & & & \\
\hline KSM 2 & 0.08 & 0.28 & 1.660 & 1.870 & 3.07 & 11 & 0.0104 \\
\hline
\end{tabular}

Source: authors' own research.

\section{Discussion}

Numerous studies have demonstrated an increase in asymmetry in the coronal plane, with a particular focus on a position of the scapulae and pelvis. In an initial period, the asymmetry has a functional character and is not accompanied by structural changes in the area of passive locomotor system. With time, however, incorrect body posture becomes permanent which, in consequence, leads to scoliosis (Nissinen, Heliovaara, Seitsamo, Alaranta, Poussa, 1994; Nissinen, Heliovaara, Seitsamo, 2000; Poussa, Heliovaara, Seitsamo, 2005). Training-induced body adaptations to the demands of a given sports discipline typically magnify the asymmetry (Starosta, 1993). Uetake and Ohtsuki (1993) found progression in the angles of thoracic kyphosis and lumbar lordosis that increased with training experience. Similar tendency compared to control group was observed by Wojtys, Ashton-Miller, Huston, Moga (2000). Other studies have shown a statistically significant effect of long-term training on the symmetry in the coronal plane and angular values of physiological curvatures in the median plane (Perrin, Deviterne, Hegel, Perrot, 2002).

Research of Kaiser, Sokołowski, Mrozkowiak (2014) on a group of 30 wrestling women displayed that physical effort of training caused serious progression of thoracic kyphosis and lumbar lordosis with simultaneous increase in partial angles (Alfa, Beta, Gamma), size, length and progression of thoracic kyphosis and lumbar lordosis. In the coronal plane positive and significant changes were found in the trunk verticality, asymmetry of shoulders, scapulae, and pelvis, while negative was progression of left side scoliosis. Further analysis showed that negative changes occur mainly in the median plane, while line features of both curvatures (height and length) increasing their values at the same time decrease angle of thoracic kyphosis and lumbar lordosis, partial angles - while increasing - cause their progression. It is, therefore, antagonistic pressure. In so far as the thoracic-lumbar angle did not reveal any 
considerable changes, the others showed substantial ones. Entirely different results were obtained in the research on a group of males from the national wrestling team, while similar ones - among judo competitors (Mrozkowiak, $2003,2004)$. It was found that muscles of the pelvis-trunk area of judo competitors, similarly to female fencers, displays smaller resistance to vertical load, deepening the angle of lumbar lordosis, length of lumbar lordosis and thoracic kyphosis, and the angle of trunk extension in the median plane.

Significant disturbances in the girls' spatial parameters of pelvis symmetry indicate deficiencies within hip joints movement and muscle dystonia in that body area, decreasing the angle in the coronal plane, which influences functionality of their vertebral column.

Fencing training of boys increased unfavourably length of scoliosis, angle of lumbar lordosis, and trunk asymmetry in the median plane. This signifies decreased strength of muscles of pelvis area, lower limbs and spine. Thus, there is a real danger that with lack of exercises correcting the abovementioned disturbances of the examined group they may with time determine the final result of competition.

\section{Conclusions}

1. Specialist fencing training of girls caused substantial disturbances in spatial parameters of pelvis, with no significant changes in values of physiological spinal curvatures and trunk symmetry. Among boys, both favourable and unfavourable occurred in the median plane, within lumbar lordosis and trunk verticality, as well as in the coronal plane in the line of spinous processes and shoulders.

2. It is necessary to adjust deficiencies within hip joints movement, and increase pelvis and lower limbs muscle strength in girls' training. What is recommended for all competitors is prophylaxis of the spinal pain syndrome and expanding endurance shaping exercises during a training unit, accommodated to a competitor's developmental age.

3. In complementary fencing training muscle strength of: pelvis area, lower limbs and spine should be underlined.

\section{References}

Alyas, F., Turner, M., Connell, D. (2007). MRI findings in the lumbar spines of asymptomatic, adolescent, elite tennis players. Br J Sports Med, 41, 836-841.

Castinel, B.H., Adam, P., Milburn, P.D. (2010). Epidemiology of cervical spine abnormalities in asymptomatic adult professional rugby union players using static and dynamic MRI protocols: 2002 to 2006. Br J Sports Med, 44, 194-199.

Flis-Masłowska, M., Trzaska, T., Wiernicka, M., Lewandowski, J. (2014). Structural lesions in the lumbosacral spine in field hockey players. Med Sport, 67 (3), 473-484.

Kaiser, A., Sokołowski, M., Mrozkowiak, M. (2014). Effects of a 90-minute wrestling training on the selected features of the shape of spine and pelvis under load. Arch Budo, 10, OA57-65.

Kingma, I., van Dieen, J.H., de Looze, M., Toussaint, H.M., Dolan, P., Baten, C.T.M. (1998). Asymmetric low back loading in asymmetric lifting movements is not prevented by pelvic twist. J Biomech, 31 (6), 527-534.

López-Miñarro, P.A., Muyor, J.M., Alacid, F. (2010). Sagittal spinal curvatures and pelvic tilt in elite young kayakers. Med Sport, 63 (4), 509-519.

Mroczkowski, A., Jaskólski, E. (2007). The change of pelvis placement at children under influence of aikido training. Arch Budo, 3, $21-26$.

Mrozkowiak, M., Kaiser, A.,Sokołowski, M. (2015). Habitual posture of fencers representing the Wielkopolska region. Arch Budo Sci Martial Art Extreme Sport, 11, 11-21.

Mrozkowiak, M., Sokołowski, M., Kaiser, A. (2012). Characteristics of habitual posture in female wrestlers from the Polish National Team. Med Sport, 65 (2), 235-251. 
Mrozkowiak, M. (2003). Analiza porównawcza krzywizn fizjologicznych kręgosłupa pod wpływem obciążenia osiowego zawodników judo i zapasów. In: E. Bulicz (ed.), Potęgowanie zdrowia. Czynniki, mechanizmy i strategie zdrowotne (pp. 346-350). Radom: Wydawnictwo i Zakład Poligrafii Instytutu Technologii Eksploatacji.

Mrozkowiak, M. (2004). Analiza porównawcza zespołu miednica-kręgosłup pod wpływem obciążenia osiowego w płaszczyźnie czołowej i poprzecznej zawodników judo i zapasów. In: D. Umiastowska (ed.), Aktywność ruchowa ludzi w różnym wieku (pp. 263-267). Szczecin: Albatros.

Mrozkowiak, M. (2011). Modulacja, wpływ i związki wybranych parametrów postawy ciała dzieci i młodzieży w wieku od 4 do 18 lat w świetle mory projekcyjnej. Zielona Góra: Oficyna Wydawnicza Uniwersytetu Zielonogórskiego.

Nakagawa, Y., Mukai, S., Hattori, Y., Nakamura, T. (2011). Spondylolysis decreases sports performance in sumo wrestlers - radiological changes of lumbar spine in high school and collegiate sumo wrestlers. Br J Sports Med, 45, 322.

Nissinen, M., Heliovaara, M., Seitsamo, J., Alaranta, H., Poussa, M. (1994). Anthropometric measurements and the incidence of low back pain in a cohort of pubertal children. Spine, 19, 1367-1370.

Nissinen, M., Heliovaara, M., Seitsamo, J. (2000). Development of trunk asymmetry in a cohort of children ages 11 to 22 years. Spine, 25 (5), 570-578.

Perrin, P., Deviterne, D., Hegel, F., Perrot, C. (2002). Judo, better than dance, develops sensorimotor adaptabilities involved in balance control. Gait Posture, 15, 187-194.

Perrot, C., Mur, J., Maynard, D., Barrault, D., Perrin, P.P. (2000). Influence of trauma induced by judo practice on postural control. Scand J Med Sci Sports, 10, 292-297.

Poussa, M.S., Heliovaara, M.M., Seitsamo, J.T. (2005). Development of spinal posture in a cohort of children from the age of 11 to 22 years. Eur Spine J, 14 (8), 738-743.

Rajabi, R., Mobarakabadi, L., Alizadhen, H.M., Hendrick, P. (2012). Thoracic kyphosis comparisons in adolescent female competitive field hockey players and untrained controls. J Sport Med Phys Fit, 52 (5), 545-550.

Shumway-Cook, A., Woollacott, M. (2000). Motor control: theory and practical applications. 2nd ed. Philadelphia: Lippincott Williams \& Wilkins Baltimore.

Starosta, W. (1993). Kształt kręgosłupa z punktu widzenia motoryki człowieka i motoryki sportowej. Post Rehab, 7 (4), 19-30.

Uetake, T, Ohtsuki, F. (1993). Sagittal configuration of spinal curvature line in sportsmen using Moiré technique. Okajimas Folia Anat Jpn, 70 (2-3), 91-103.

Wojtys, E.M., Ashton-Miller, J.A., Huston, L.J., Moga, P.J. (2000). The association between athletic training time and the sagittal curvature of the immature spine. Am J Sports Med, 28 (4), 490-498.

Yung, R.S., Andrew, P.D., (2000). Cummings GS. Effect of simulating leg length ineguality on pelvic torsion and trunk mobility. Gait and Posture, $11,217-223$.

Cite this anticle aS: Kaiser, A., Sokołowski, M., Mrozkowiak, M. (2017). Influence of Fencing Training (Technical and Tactical) on Selected Features of Shape of the Spine and Pelvis Under Load. Central European Journal of Sport Sciences and Medicine, 18 (2), 33-40.

DOI: 10.18276/cej.2017.2-04. 